\title{
Afyonkarahisar İlinde Satışa Sunulan Tavuk Eti ve Sakatatlarında Salmonella spp. Varlı̆̆ının Belirlenmesi ${ }^{\#}$
}

\author{
Ulaş ACARÖZ1ํ, Zeki GÜRLER ${ }^{1 *}$, Recep KARA¹, Damla ARSLAN-ACARÖZ², Fahriye ZEMHERİ ${ }^{3}$ \\ 1 Afyon Kocatepe Üniversitesi Veteriner Fakültesi, Besin Gida Hijyeni ve Teknolojisi Anabilim Dal, Afyonkarabisar, Türkiye \\ 2 Afyon Kocatepe Üniversitesi, Bayat Meslek. Yü̈ksek. Okulu, Laborant ve Veteriner Sağlk. Bölümü, Afyonkarabisar, Türkiye \\ ${ }^{3}$ Bartın Üniversitesi, Fen Fakëlltesi, Moleküller Biyoloji ve Genetik. Bölümü, Biyoteknoloji Anabilim Dah, Bartın, Türkiye \\ \#Bu çalıșma Afyon Kocatepe Üniversitesi, Bilimsel Araştrmalar Koordinasyon Birimi tarafindan 16.KARIYYER.144 proje \\ numarası ile desteklenmiștir.
}

*Corresponding author e-mail: zgurler@aku.edu.tr

\begin{abstract}
ÖZ
Doğada yaygın olarak bulunan Salmonella etkenleri, insan ve hayvanlarda perakut septisemi, akut ve kronik enteritis ile karakterize infeksiyonlara yol açmakta olup hayvanlar arasında bulaşma eğiliminin hızlı olması nedeniyle ekonomik önem taşımaktadır. Bu çalışmada, Afyonkarahisar'da satışa sunulan tavuk eti ve sakatatlarının Salmonella spp. kontaminasyonu bakımından taşıdığ halk sağlığ risklerini değerlendirmek amaçlanmıştır. Bu amaçla, Afyonkarahisar ilinde satışa sunulan but (20), göğüs (20), kanat (20), taşlık (20) ve karaciğer (20) olmak üzere toplam 100 adet tavuk eti ve sakatat örneği toplanmış ve ISO 6579 referans metodu ile analiz edilmiştir. Bu örneklerden but (1), karaciğer (1) ve kanat (1) olmak üzere toplam 3 (\%3) adet Salmonella spp. izole edilmiştir ve elde edilen izolatlar PCR ile doğrulanmışır. Sonuç olarak, Afyonkarahisar'da tüketime sunulan tavuk eti ve sakatatlarında Salmonella spp. kontaminasyon düzeyi düşük bulunmasına karşın, tavuk etleri Salmonella spp. varlığı açısından önemli bir kaynaktır. Bu nedenle, koruyucu önlemlerin alınması ve tüketicinin gıda güvenliği açısından bilgilendirilmesi önerilmektedir.
\end{abstract}

Anahtar kelimeler: Salmonella spp., tavuk eti, sakatat, hijyen

Presence of Salmonella spp. in Chicken Meat and Giblets Marketed in Afyonkarahisar Province

\begin{abstract}
Salmonella spp., commonly found in nature and cause infections characterized by peracute septicemia, acute and chronic enteritis in humans and animals, can cause economic concerns due to the rapid transmission tendency among animals. This study aimed to evaluate the public health risks of the chicken meat and giblets marketed in Afyonkarahisar regarding the presence of Salmonella spp. For this purpose, totally, 100 chicken meat and giblet samples including drumstick (20), breast meat (20), wing (20), gizzard (20), and liver (20) samples were collected from Afyonkarahisar province and analyzed according to the ISO 6579 reference method. A total of $3(3 \%)$ Salmonella spp. were isolated from drumstick (1), liver (1), wing (1) samples and the isolates were confirmed by PCR. In conclusion, although the Salmonella spp. contamination level of chicken meat and giblets marketed in Afyonkarahisar province found to be low, chicken meat is an important source for Salmonella species. Therefore, it is recommended to take preventive measures and inform the consumer regarding food safety.
\end{abstract}

Keywords: Salmonella spp., chicken meat, giblets, hygiene 


\section{GİRIŞ}

Kanatlı eti, esansiyel aminoasitler, doymamış yağ asitleri, B grubu vitaminler bakımından zengin, bağ doku oranı az, sindirimi kolay ve düşük kalorili hayvansal bir gıdadır (Çalıcıoğlu 2010; Tonbak ve ark. 2017). Kanatlı eti (özellikle piliç eti) üretimi ve tüketimi, sağlıklı bir içeriğe sahip olması, kırmızı ete oranla ekonomik olması, hazırlama kolaylı̆g gibi nedenlerle Türkiye'de ve dünya genelinde bir artış göstermektedir (Keskin ve Demirbaş 2012; Dokuzlu ve ark. 2013). Bununla birlikte, kanatlı eti mikroorganizmaların üremeleri için de yüksek besin değerinden dolayı oldukça uygun bir ortamdır (Tonbak ve ark. 2017). Günümüzde artan kanatlı eti üretimi ve tüketimi belirli halk sağllğ1 problemleriyle ilisskilendirilmektedir. Bunlardan en yaygin olanlarndan biri bakteriyel ve zoonoz bir etken olan Salmonella spp.'dir (Oral ve Türkyllmaz 2008; Siriken ve ark. 2015). Tüketime sunulan tavuk karkaslarının ve parça etlerin elde edilmesi sırasında uygulanan iç organların çıkarılması, soğutma, paketleme, transport gibi aşamalar bu bakterilerin kontaminasyonu açısından potansiyel bir risk oluşturmaktadır. Gelişen ve gelişmekte olan ülkelerde gida kaynaklı enfeksiyonların en önemli nedenlerinden biri olan Salmonella etkenleri yüksek morbiditeye sahip ve birçok gida ile ilişkilendirilmekte olup, bu bakterinin neden olduğu Salmonelloz önemli bir halk sağlığı problemidir (de Freitas ve ark. 2010; Abd-Elghany ve ark. 2015). İnsan salmonelloz salginları, siklıkla çiğ ve az pişirilmiş kanatlı eti, ürünleri ve yumurta tüketimiyle ilişkilendirilmektedir (Iseri ve Erol 2010). Halk sağlı̆ı için oluşturacağ1 potansiyel tehlikelerden dolayı kanatlı etlerinin ve ürünlerinin Salmonella varliğ1 yönünden kontrolü önem arz etmektedir. Türkiye'de (Dümen ve ark. 2015; Al ve ark. 2016; Goncuoglu ve ark. 2016) ve diğer ülkelerde (Jerngklinchan ve ark. 1994; Van Nierop ve ark. 2005; Abd-Elghany ve ark. 2015) tavuk eti ve sakatatlarında Salmonella spp. varlığını araştıran çalışmalarda bu etkenin önemli bir bakteriyel kontaminasyon kaynağ1 olduğu görülmektedir.

$\mathrm{Bu}$ çalışmada, Afyonkarahisar ilinde tüketime sunulan tavuk etleri ve sakatatlarının önemli gida kaynaklı bir zoonoz olan Salmonella spp. varllğ1 yönünden klasik kültür metodu ve PCR metodu kullanılarak incelenmesi amaçlanmıştır.

\section{MATERYAL ve METOT}

Bu çalışmada Afyonkarahisar ilinde satışa sunulan kanatlı eti ürünlerinde Salmonella türlerinin varlığını belirlemek amaciyla Haziran-Aralık 2017 tarihleri arasında toplanan beș farklı kanatlı eti ürününe (taşlık, karaciğer, but, göğüs eti, kanat) ait örneklerden 20'şer adet olmak üzere toplam 100 örnek analiz edilmiştir.

Her bir kanatlı eti ve sakatat örneğinden $25 \mathrm{~g}$ tartılarak üzerine $225 \mathrm{ml}$ tamponlanmış peptonlu su ilave edildi. Numuneler stomacherde homojenize edilerek $37 \pm 1^{\circ} \mathrm{C}^{\prime} \mathrm{de} \quad 18 \pm 2$ saat inkübasyona bırakıldı. İnkübasyondan sonra, ön zenginleştirme sivisindan sirasiyla $0,1 \mathrm{ml}$ ve $1 \mathrm{ml}$ alınarak Rapoport Vasilliadis Soya Pepton Broth'a ve Muller-Kauffmann Tetrathionate-novobiocin Broth'a aktarld. Besiyerleri sirasiyla $41,5 \pm 1^{\circ} \mathrm{C}$ ve $37 \pm 1^{\circ} C^{\prime}$ de $24 \pm 3$ saat inkübe edildi. Bu aşamadan sonra, selektif besiyerlerinden alınan örnekler Xylose-Lysine-Deoxycholate Agar ve Modified Brillant Green Agar'a çizildi ve $37 \pm 1^{\circ} \mathrm{C}^{\prime}$ de $24 \pm 3$ saat inkübasyona birakıldı. İnkübasyondan sonra Salmonella şüpheli koloniler Tryptone Soya Agar üzerine çizilerek saflaştırıldı. Daha sonra, izole edilen kolonilere biyokimyasal ve serolojik testler uygulandı (Anonim 2002).

Elde edilen Salmonella spp. şuşlarının DNA'sı ticari DNA izolasyon kiti (Qiagen DNeasy® DNA İzolasyon Kiti, Almanya) kullanılarak, üretici firma talimatlarına göre ekstrakte edildi. Ekstrakte edilen DNA'lar agaroz jelde görüntülenerek, DNA absorbanslar1 MultiskanTM FC Mikroplate Fotometre (Thermo, ABD) cihazında $\mu$ Drop spektrofotometride ölçüldü. Primer tasarımında Salmonella spp.'e özgü invA genine ait DNA dizisine göre tasarlanan primerler (Forward: GTGAAATTATCGCCACGTTCGGGCAA; Reverse: TCATCGCACCGTCAAAGGAACC) kullanıldı (Yuan ve ark. 2009). PCR karışımı her bir örnek için DNA $(2 \mu \mathrm{l})$, primerler $(0,2 \mu \mathrm{M})$, $\mathrm{MgCl}_{2}(1,5 \mathrm{mM}), 10 \mathrm{x}$ buffer solüsyonu, dNTPler $(0,2 \mathrm{mM})$ ve $3 \mathrm{U}$ Platinum Taq DNA Polimeraz 25 $\mu$ l'lik final hacimde olacak şekilde hazırlandı.

PCR işlemi T100TM Thermal Cycler (Bio-Rad, ABD) kullanılarak aşağıda belirtilen koşullarda gerçekleştirildi;

$\left.\begin{array}{l}\text {-Ön denatürasyon } 95^{\circ} \mathrm{C}, 3 \mathrm{dk} \\ \text {-Denatürasyon } 95^{\circ} \mathrm{C}, 30 \mathrm{sn} \\ \text {-Primer yapışmas } 60^{\circ} \mathrm{C}, 30 \mathrm{sn} \\ \text {-Uzatma } 72^{\circ} \mathrm{C}, 30 \mathrm{sn} \\ \text {-Son uzatma basamağ } 72^{\circ} \mathrm{C}, 5 \mathrm{dk}\end{array}\right\} 40$ döngü

PCR ürünleri ve marker \%2'lik agaroz jel elektroforezinde yürütülerek UV altında görüntülendi.

\section{BULGULAR}

Yapılan çalışmada toplanan parça tavuk eti örneklerinden kanat eti, but eti ve karaciğer örneklerinde 1'er adet Salmonella spp. izole edilmiş 
olup; toplamda 100 parça tavuk eti örneğinde 3 (\%3) adet Salmonella spp. tespit edildi. Analiz edilen parça tavuk eti örneklerinden (kanat eti, göğ̈̈s eti, but eti, karaciğer, taşlık) izole edilen Salmonella spp. sayıları Tablo 1'de gösterildi. Biyokimyasal ve serolojik testler ile doğrulanan izolatlar PCR ile onayland1 (Şekil 1).

Tablo 1. Analiz edilen tavuk eti ve sakatatlarında Salmonella spp. varlığ1

Table 1. Presence of Salmonella spp. in the analyzed chicken meat and giblets

\begin{tabular}{lcc}
\hline Numune & Numune Sayıs1 & Pozitif Numune Sayıs (\%) \\
\hline Tavuk Kanat Eti & 20 & $1(\% 5)$ \\
Tavuk Göğüs Eti & 20 & - \\
Tavuk But Eti & 20 & $1(\% 5)$ \\
Tavuk Karaciğer & 20 & $1(\% 5)$ \\
Tavuk Taşlık & 20 & - \\
\hline Toplam & 100 & $3(\% 3)$ \\
\hline
\end{tabular}

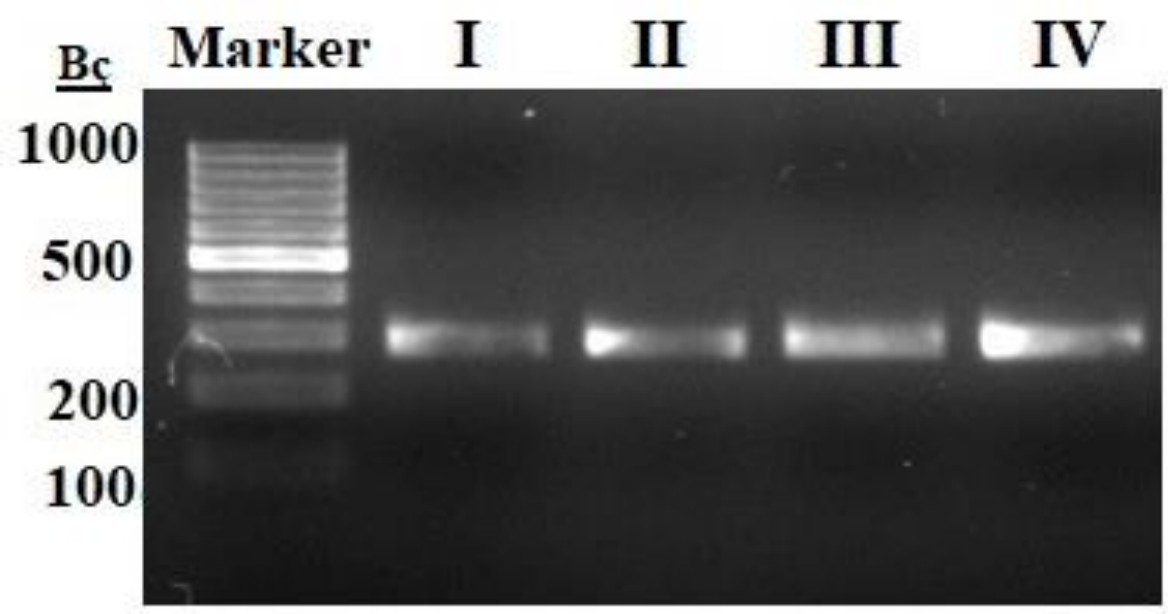

Şekil 1. Salmonella spp. pozitif örneklerin PCR sonuçları (I: Pozitif Kontrol, II: Kanat, III: But, IV: Karaciğer)

Figure 1. PCR results of Salmonella spp. positive samples (I: Positive Control, II: Wings, III: Drumstick, IV: Liver)

\section{TARTIŞMA}

En önemli patojen bakterilerden biri olan Salmonella, gıda kaynaklı hastalık ve salgınlara neden olabilmektedir (Gouws ve ark. 1998). Dünyada en çok tüketilen hayvansal ürünler arasında olan kanatlı eti ve ürünleri insan salmonellozu'nun en önde gelen sebebidir (Gupta ve ark. 1999; Al ve ark. 2016). Türkiye'de ve dünyada kanatlı eti ve sakatatlarında Salmonella spp. varlığını araştıran pek çok çalışma yapılmıştır. Cetinkaya ve ark. (2008) Bursa ilinde marketlerde satışa sunulan 168 adet parça tavuk eti örneğinin sadece \%0,6 oranında Salmonella spp. ile kontamine olduğunu bildirmişlerdir. Başka bir çalışmada, Aydın ve İzmir illerinde bulunan broyler ve broyler damızlık işletmelerinden salmonellozis şüpheli 422 kanatliya ait karaciğer ve kalp örneklerinde sırasıyla \%2,4 ve
\%1,7 oraninda Salmonella spp. izole edildiği bildirilmiştir (Oral ve Türkyılmaz 2008). Ozbey ve Ertas (2006), Elazı $\breve{g}$ ilindeki bir kesimhaneden temin ettikleri toplam 250 adet tavuğa ait karaciğer örneklerinin Salmonella spp. kontaminasyon düzeyini \%4 olarak bildirmişleridir. Sezen (2009) İstanbul piyasasında ambalajlı olarak tüketime sunulan 50 adet piliç but ve 50 adet piliç kanat örneğinin Salmonella spp. kontaminasyon seviyesini s1rasıyla \%6 ve \%2 olarak belirlemiştir. İstanbul'da yapılan başka bir çalışmada ise tüketime sunulan 50 adedini süpermarketlerden, 50 adedi ise kasaplardan toplanan 100 çiğ tavuk karkasında Salmonella spp. kontaminasyon düzeyi \%15 olarak belirlenmiştir (Dümen ve ark. 2015). Al ve ark. (2016) 50 karaciğer ve 42 taşlik olmak üzere toplam 92 kanatlı sakatatındaki Salmonella spp. kontaminasyon düzeyini s1rasiyla $\% 27$ ve $\% 18$ 
olarak belirlemişlerdir. Goncuoglu ve ark. (2016) Ankara'da satışa sunulan her birinden 110 adet olmak üzere broyler karkasları, kanat ve karaciğer örneklerindeki Salmonella spp. kontaminasyon düzeyini sirasiyla $\% 25,4, \% 28,1$ ve $\% 33,6$ olarak bildirmişlerdir. Ankara'da gerçekleştirilen başka bir çalışmada ise 50 adet poşetlenmiş bütün tavuk karkasına ait olan but ve göğüs örneklerinin Salmonella spp. bakımından incelenmiş ve kontaminasyon düzeyi butlarda $\% 18$, göğüs örneklerinde ise \%16 düzeyinde belirlenmiştir (Efe ve Gümüsssoy 2005). Konya'da tüketime sunulan 168 tavuk karkaslarında yapılan bir çalışmada ise bu bakteri için kontaminasyon düzeyi $\% 32,7$ olarak bildirilmiştir (Hadimli ve ark. 2006). Samsun'da süpermarketlerden temin edilen 75 karkas ve 75 parça et olmak üzere toplam 150 adet tavuk eti klasik kültür metodu ve immunomagnetik separasyon metodu kullanilarak Salmonella spp. varlığı yönünden incelenmiş olup, klasik kültür metoduna göre kontaminasyon düzeyi $\% 25,3$ olarak belirlenirken, immunomagnetik separasyon tekniğine göre kontaminasyon düzeyi $\% 36$ olarak belirlenmiştir (Siriken ve ark. 2015). Tokat'ta tüketime sunulan 25 adet tavuk göğsü ve 25 adet tavuk butlarını Salmonella spp. kontaminasyon düzeyi sırasıyla $\% 44$ ve $\% 52$ olarak bildirilmiştir (Yıldırım ve ark. 2015). Bununla birlikte, diğer ülkelerde de Salmonella türlerinin kanatlı eti ve sakatatlarında varlığını inceleyen çok sayıda araştırma mevcuttur. Brezilya'da yapilan bir çalışmada 127 tavuk karkası örneğinin hiçbirinin Salmonella spp. ile kontamine olmadığını bildirilmiştir. Bununla birlikte bu bakteri için 73 sakatat örneğindeki (kalp, taşlık ve karaciğer) kontaminasyon düzeyi $\% 2,74$ olarak bildirilmiştir (de Freitas ve ark. 2010). Arjantin'de yapilan bir çalışmada ise 62 kanatlı sakatat örneğinin kontaminasyon düzeyi $\% 3,2$ olarak bildirilmiştir (Favier ve ark. 2013). Rodrigo ve ark. (2006) Trinidad'da yaptıkları bir çalışmada tavuk karkas, taşlık, karaciğer ve kalp örneklerindeki Salmonella kontaminasyon düzeyini sirasıly $\% 7,3, \% 2,1$ ve $\% 1$ olarak belirlemişlerdir. Güney Afrika'da taze ve dondurulmuş tavuk karkaslarında gerçekleştirilen bir çalışmada Salmonella kontaminasyon düzeyi \%19,2 olarak bildirilmiştir (Van Nierop ve ark. 2005). Abd-Elghany ve ark. (2015) Misır'da yapmış oldukları çalışmada tavuk karkasları, baget, karaciğer ve taşlıkta Salmonella spp. kontaminasyon düzeyini sırasiyla $\% 16, \% 28, \% 32$ ve $\% 60$ olarak saptamışlardır. Tayland'da gerçekleştirilen bir çalışmada ise 705 tavuk eti örneğinin Salmonella kontaminasyon düzeyi $\% 66$ olarak belirlenirken, 221 sakatat örneğinin kontaminasyonunu \%86 olarak bildirilmiştir (Jerngklinchan ve ark. 1994). Dünyada ve Türkiye'de tavuk eti ve sakatlarında yapılan çalışmalarda farklı oranlarda Salmonella spp. varlı̆̆ rapor edilmiş olup çalışmamızda elde edilen sonuçlar bu oranlar arasında bulunmaktadır. Salmonella spp. kontaminasyon düzeyindeki farkl111klara hayvanların beslenme, nakliye ve kesim koşulları ile örnek alma, örnek sayısı ve büyüklüğündeki değișkenlikler neden olabilmektedir. Sonuç olarak, Afyonkarahisar'da satışa sunulan kanatlı eti ve sakatlarında Salmonella spp.'nin (\%3) yaygin olarak bulunmadığ1 belirlenmiştir. Bununla birlikte, kanatlı etlerinin Salmonella spp. varlığı açısından önemli bir kaynak olduğu göz önüne alındığında, etkenin kanatlı etlerinden bu patojenin eliminasyonu için, öncelikle tüm üretim prosesinde çiftlikten çatala prensibi ile HACCP, GMP ve GHP sistemlerinin eksiksiz ve düzenli bir şekilde uygulanması, çapraz kontaminasyonun engellenmesi, tüketicilerin bilinçlendirilmesi, risk grubu gıdaların periyodik düzenli kontrollerinin yapılması önerilmektedir.

\section{KAYNAKLAR}

\section{Abd-Elghany SM, Sallam KI, Abd-Elkhalek A,} Tamura T. Occurrence, genetic characterization and antimicrobial resistance of Salmonella isolated from chicken meat and giblets. Epidemiol. Infect. 2015;143(5): 997-1003.

Al S, Hizlisoy H, Onmaz NE, Yildirim Y, Gönülalan Z. Occurrence and antimicrobial resistance of Salmonella enterica subsp. enterica serovars Typhimurium, Enteritidis, and Typhi isolated from chicken eggs and poultry products. TURKISH J. Vet. Anim. Sci. 2016;40(6): 737-43.

Anonim 2002. Microbiology of Food and Animal Feeding Stuffs-Horizontal Method for the Detection of Salmonella spp., International Standard, ISO (International Standardization Organization) 6579: 2002, Geneva, Switzerland Switzerland.

Çalıcıoğlu M. Kesimhanede Salmonella Kontrolü: Uygulamalar ve Pratik Yaklaşımlar. Türkiye Klin. J Vet Sci. 2010;1(298-104).

Cetinkaya F, Cibik R, Ece Soyutemiz G, Ozakin C, Kayali R, Levent B. Shigella and Salmonella contamination in various foodstuffs in Turkey. Food Control. 2008;19(11): 1059-63.

Dokuzlu S, Ş OB, Hecer C, Ş MG. Türkiye' de Tavuk Eti Tüketim Alışkanlıkları ve Marka Tercihleri. J. Agric. Fac. Uludag Univ. 2013;92(2): 83-92.

Dümen E, Aydın A, Issa G. Çiğ Tavuk Karkaslarından İzole Edilen Salmonella 
Typhimurium, Salmonella Enteritidis ve Salmonella spp.'nin Prevalans, Serolojik Tiplendirme ve PCR Hassasiyetinin Karşılaştırılması. Kafkas Univ. Vet. Fak. Derg. 2015;21(5): 653-8.

Efe M, Gümüşsoy KS. Ankara Garnizonu'nda tüketime sunulan tavuk etlerinin mikrobiyolojik analizi. Sağlık Bilim. Derg. J. Heal. Sci. 2005;14(3): 151-7.

Favier GI, Lucero Estrada CSM, Lazarte Otero V, Escudero ME. Prevalence, antimicrobial susceptibility, and molecular characterization by PCR and pulsed field gel electrophoresis (PFGE) of Salmonella spp. isolated from foods of animal origin in San Luis, Argentina. Food Control. Elsevier Ltd; 2013;29(1): 49-54.

de Freitas CG, Santana ÂP, da Silva PHC, Gonçalves VSP, Barros M de AF, Torres FAG, Murata LS, Perecmanis S. PCR multiplex for detection of Salmonella Enteritidis, Typhi and Typhimurium and occurrence in poultry meat. Int. J. Food Microbiol. Elsevier B.V.; 2010;139(1-2): 1522.

Goncuoglu M, Ormanci FSB, Uludag M, Cil GI. Prevalence and Antibiotic Resistance of Salmonella SPP. and Salmonella Typhimurium in Broiler Carcasses Wings and Liver. J. Food Saf. 2016;36(4): 524-31.

Gouws PA, Visser M, Brozel VS. A polymerase chain reaction procedure for the detection of Salmonella spp. within 24 hours. J. Food Prot. 1998;61(8): 1039-42.

Gupta V, Ray P, Sharma M. Antimicrobial resistance pattern of Shigella and non-typhi Salmonella isolated from patients with diarrhoea. Indian J. Med. Res. 1999;109: 435.

Hadimli HH, Erganiş O, Güner A, Öztürk D, Kav K. Konya İlinde Perakende Satışa Sunulan Tavuk Etlerinde Salmonella Spp. ve Campylobacter Spp. Varlığı'nın Araştırılması. Vet. Bilim. Derg. 2006;22(34): 31-4.

Iseri O, Erol I. Incidence and antibiotic resistance of Salmonella spp. in ground turkey meat. Br. Poult. Sci. 2010;51(1): 60-6.

Jerngklinchan J, Koowatananukul C, Daengprom K, Saitanu K. Occurance of Salmonellae in Raw Broilers and Their Products in Thailand. J. Food Prot. 1994;57(9): 808-10.
Keskin B, Demirbaş N. Türkiye'de Kanatlı Eti Sektöründe Ortaya Çıkan Gelişmeler: Sorunlar ve Öneriler. J. Agric. Fac. Uludag Univ. 2012;26(1): 117-30.

Oral Aİ, Türkyılmaz S. Broyler İç Organlarından Salmonella enterica subsp . enterica serovar Enteritidis ' in İzolasyonu ve İzole Edilen Suşların Antibiyotiklere Duyarlılıklarının Belirlenmesi. Erciyes Üniv Vet Fak Derg. 2008;5(1): 27-33.

Ozbey G, Ertas HB. Salmonella Spp . Isolation From Chicken Samples and Identification By Polymerase Chain Reaction. Bulg. J. Vet. Med. 2006;9(1): 67-73.

Rodrigo S, Adesiyun A, Asgarali Z, Swanston W. Occurrence of selected foodborne pathogens on poultry and poultry giblets from small retail processing operations in Trinidad. J. Food Prot. 2006;69(5): 1096105.

Sezen G. Piyasada Satışa Sunulan Taze Kanatlı Eti Preparatlarının Son Kullanma Tarihlerindeki Duyusal, Kimyasal ve Mikrobihyolojik Kaliteleri. Uludag Univ. J. Fac. Vet. Med. 2009;28(1): 19-24.

Siriken B, Türk H, Yildirim T, Durupinar B, Erol I. Prevalence and characterization of salmonella isolated from chicken meat in Turkey. J. Food Sci. 2015;80(5): M1044-50.

Tonbak F, Atasever M, Çalıcıoğlu M. Kanatlı Etlerinde Salmonella Riski. Atatürk Üniversitesi Vet. Bilim. Derg. 2017;12(1): 90-8.

Van Nierop W, Dusé AG, Marais E, Aithma N, Thothobolo N, Kassel M, Stewart R, Potgieter A, Fernandes B, Galpin JS, Bloomfield SF. Contamination of chicken carcasses in Gauteng, South Africa, by Salmonella, Listeria monocytogenes and Campylobacter. Int. J. Food Microbiol. 2005;99(1): 1-6.

Yıldırım Z, Ceylan Ş, Öncül N. Tokat Piyasasında Satışa Sunulan Tavuk Etlerinin Mikrobiyolojik Kalitesinin Belirlenmesi. Akad. Gida. 2015;13(4): 304-3016.

Yuan Y, Xu W, Zhai Z, Shi H, Luo Y, Chen Z, Huang K. Universal primer-multiplex pcr approach for simultaneous detection of escherichia coli, listeria monocytogenes, and salmonella spp. in food samples. J. Food Sci. 2009;74(8). 